〈報 告〉

\author{
看護管理者を対象とした手指衛生向上プログラムの検証： \\ 手指消毒薬使用率と MRSA 発生率について

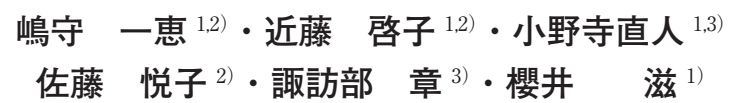

\title{
Verification of Hand Hygiene Improvement Program for Nursing Administrators: Alcohol Based Hand Rub Usage and Detection Number of Methicillin-resistant Staphylococcus aureus
}

\author{
Kazue ShImAmori ${ }^{1,2)}$, Keiko Kondou ${ }^{1,2)}$, Naoto OnODERA ${ }^{1,3)}$, \\ Etsuko SATO ${ }^{2)}$, Akira SUWABE ${ }^{3)}$ and Shigeru SAKURAI ${ }^{1)}$ \\ 1) Infection Control Office, Department of Medical Safety Administration, Iwate Medical University Hospital, \\ ${ }^{2)}$ Department of Nursing, Iwate Medical University Hospital, \\ ${ }^{3)}$ Department of Laboratory Medicine, Iwate Medical University School of Medicine
}

(2016 年 12 月 28 日受付 $\cdot 2017$ 年 7 月 13 日受理)

\begin{abstract}
要 旨
手指衛生は医療関連感染防止のために重要な感染対策であるが，その遵守は十分ではない。我々 は, 看護管理者に積極的な関与を促す「手指衛生向上プログラム」の導入が, 擦式アルコール手指 消毒薬（ABHR）使用率（L/1,000patient-days）とメチシリン耐性黄色ブドウ球菌（MRSA）発生 率（件数/1,000patient-days）に与える影響を検討した．本プログラムは看護部目標の成果尺度と して, ABHR 使用率を一般病棟で 15, クリティカル部門で 30 と設定し, 各看護師長に目標達成を 義務付けた。また，看護師長会議で毎月の ABHR 使用率と MRSA 検出数を報告し, リンクナース と感染症対策室が目標達成の支援を行った。 その結果, 一般病棟の ABHR 使用率は, 導入前の平 成 25 年度は 9.3 であったが, 導入後の平成 27 年度は 17.5 に増加し $(p<0.05)$, 目標を達成した。 同時期の MRSA 発生率は 0.52 から 0.37 に減少した $(p<0.05)$. クリティカル部門の ABHR 使用 率も, 平成 25 年度の 41.9 から, 平成 27 年度では 78.8 に増加し $(p<0.05)$, MRSA 発生率も 1.84 から 1.63 へと減少傾向を示した. 以上により, 手指衛生の推進を看護部の目標とし, 病棟の中心 的存在である看護師長の関与のもと組織全体が積極的に取り組むことが効果的であり，本プログラ ムは手指衛生の向上に有用であることが示唆された.
\end{abstract}

Key words : 手指衛生, 擦式アルコール手指消毒薬, メチシリン耐性黄色ブドウ球菌, 看護管理者

序文

手指衛生は医療関連感染防止のために重要とされてい る感染対策の一つであるが，その遵守は未だ十分な水準 に達していない(1 3). その原因は, 手指衛生に関する知 識や技術不足だけではなく, 手洗い環境の不備や人員不 足, 手指衛生に伴う手荒れの問題など多岐にわたってい $る^{4.5)}$. 手指衛生の強化を目的に, 職員教育や啓発, 手指

1)岩手医科大学附属病院医療安全管理部感染症対策室, 2)岩手医科 大学附属病院看護部, 3) 岩手医科大学医学部臨床検査医学講座
消毒薬の設置場所を工夫することによる擦式アルコール 手指消毒薬（alcohol based hand rub：ABHR）の使用 率増加が報告されている ${ }^{6}$. また，文字や色などの表示 による視覚喚起やビデオを活用し，実施すべき手指衛生 の夕イミングを視覚的に教育する方法など様々な取り組 みが行われている ${ }^{7.8)}$. 一方で, 効果的に手指衛生を向上 させるためには, 施設の管理者が感染対策の重要性に理 解を示し, 積極的に関与することが不可欠とされている9). しかし，本邦では，実際に看護管理者が手指衛生に積極 的に関与し, 結果として手指衛生の向上に寄与した報告 
は少ない。岩手医科大学附属病院（以下，当院）では, 平成 25 年度からリンクナースと感染症対策室が中心に, ABHR 使用率の目標值設定や手指衛生向上のための教 育・啓発，手洗い環境の整備などを統一的に行った。 そ の結果, ABHR 使用率は増加したものの, その効果は 十分ではなかった。そこで新たに, 病棟で中心的な存在 である看護師長に対する積極的な関与を促す「手指衛生 向上プログラム (以下本プログラム)」の追加導入を行 い，本プログラムが ABHR 使用率およびメチシリン耐 性黄色ブドウ球菌（MRSA）発生率に与える影響を調 査し，その有用性について検証した。

\section{材料と方法}

\section{1. 施設の概要}

当院は一般病床 1,088 床, 精神科病床 78 床, 循環器 医療センター, 歯科医療センター, 高度救急救命センター を併設する特定機能病院・臨床研修指定病院である，標 榜診療科は 48 科で, 平成 28 年 4 月現在の平均在院日数 が 14.3 日の急性期病院である。感染症対策室は医療安 全管理部に所属し, 専任医師 (Infection Control Doctor) が 1 名, 専従感染管理認定看護師が 3 名, 専任薬剤師(感 染制御専門薬剂師 1 名）が 2 名, 専従事務員が 1 名で構 成されている。リンクナースは, 各病棟から 1 名（合計 30 名）選出されており, 医療安全管理部の組織に位置 付けられ，感染症対策室の指示のもと活動している.

\section{2. 研究対象および研究期間}

施設内 25 病棟 (一般病棟 : 19 病棟, クリティカル部 門：6病棟）の看護師長 24 名を対象として, 平成 25 年 4 月から平成 28 年 3 月における本プログラムの導入と その有用性を検証した。 なお, リンクナースと感染対策 室が中心に介入した平成 25 年度（平成 25 年 4 月〜平成 26 年 3 月）をプログラム導入前とし，プログラム導入 期間の平成 26 年度〜平成 27 年度（平成 26 年 4 月〜平 成 28 年 3 月）と比較評価した。 また, クリティカル部 門は，集中治療室（ICU）および新生児特定集中治療室 (NICU), 母体胎児集中治療管理室 (MFICU), 救急七 ンター（ER）とした。なお，一般病棟の産婦人科とク リティカル部門の MFICU の担当看護師長は兼任してい る.

\section{3. プログラム導入前に行った手指衛生向上のための} 介入（平成 25 年度）とその効果

リンクナースと感染症対策室が中心に, ABHR 使用 率の目標值設定を行った。目標值とする ABHR 使用率 (L/1,000patient-days) は, 一般病棟で 15, クリティカ ル部門で 30 に設定した。 なお, 目標值の設定は, Pittet $ら^{10)}$ が行なった病院施設における手指衛生遵守率改善の ための一般的な介入によって得られた ABHR の使用率 および世界保健機構 (World Health Organization :
WHO）が公表した手指衛生のためのガイドライン ${ }^{11)}$ 参考に設定した。また，手指衛生向上のための教育（手 指衛生の基本および技術に関する研修), 手指衛生啓発 ポスターの作成，手指消毒薬の適正配置などについて統 一的に行った。しかしながら, 一般病棟の ABHR 使用 率は，ほとんどの部署で目的達成が認められず，介入効 果は十分ではなかった（表 1).

\section{4. 看護管理者を対象とした手指衛生向上プログラム (平成 26 年度および平成 27 年度) \\ 1）手指衛生向上のための組織的な介入}

これまで看護部では，感染対策の一環として，感染症 の発生率に注目した目標を設定し, 手指衛生の強化につ いては各病棟の努力目標としていた，そこで，平成 26 年度および平成 27 年度は, 看護部目標の成果尺度の一 つとして, 感染管理の基本的対策とされる手指衛生の推 進を義務付け, ABHR 使用率の目標設定，手指衛生向 上のためのデータフィードバック，リンクナースと感染 症対策室が中心とした目標達成のための継続支援を行っ た。なお，支援内容は，プログラム導入前と同様に，手 指衛生向上のための教育, 手指衛生啓発ポスターの作成, 手指消毒薬の適正配置などについて統一的に行った。

\section{2) $\mathrm{ABHR}$ 使用率の目標設定}

目標設定については，ABHR 使用率（L/1,000patientdays）をプログラム導入前と同様に，一般病棟で 15 , ク リティカル部門で 30 に設定し, 看護師長に対する周知 徹底を行った。

3）手指衛生向上のためのデータフィードバック

看護師長会議において, 毎月の ABHR 使用率と MRSA の検出数を報告し, 目標達成のための協力を促 した. ABHR 使用率は,リンクナースが毎月計測し, MRSAの検出数は, 院内感染対策委員会の毎月の耐性 菌報告から抽出した。

\section{5. 導入したプログラムの検証}

本研究での主要評価指標は, 導入前の平成 25 年度と 導入後の平成 26 年度および平成 27 年度における月ごと の 1,000 入院患者のべ日数あたりの $\mathrm{ABHR}$ 使用量およ び新規 MRSA 検出数として, 一般病棟とクリティカル 部門，および病棟別に比較した。また，それぞれの指標 は以下のように算出した.

- ABHR 使用率 $(\mathrm{L} / 1,000$ patient-days $)=\{\mathrm{ABHR}$ 使 用量 $(\mathrm{L}) /$ 入院患者のべ日数 $\} \times 1,000$

- MRSA 発生率 (件 数/1,000patient-days) $=\{$ 新 規 MRSA 検出数（件) / 入院患者のべ日数 $\} \times 1,000$

なお, MRSA は, 全自動微生物検査システムマイク ロスキャン WalkAway 96 SI (ベックマン・コールター) を用いて同定および感受性を測定し, oxacillinの発育阻 止濃度 $(\mathrm{MIC}) \geqq 4 \mu \mathrm{g} / \mathrm{mL}$, Cefoxitin の $\mathrm{MIC} \geqq 8 \mu \mathrm{g} / \mathrm{mL}$ を示した株を MRSA とした。新規検出数は，月ごとに 
表 1 一般病棟およびクリティカル部門における年度別 ABHR 使用率と MRSA 発生率

\begin{tabular}{|c|c|c|c|c|c|c|}
\hline \multirow{2}{*}{ 一般病棟 } & \multicolumn{3}{|c|}{$\begin{array}{c}\text { ABHR 使用率 } \\
\text { (L/1,000patient-days) }\end{array}$} & \multicolumn{3}{|c|}{$\begin{array}{c}\text { MRSA の発生率 } \\
\text { (件数/1,000 patient-days) }\end{array}$} \\
\hline & $\mathrm{H} 25$ & $\mathrm{H} 26$ & $\mathrm{H} 27$ & $\mathrm{H} 25$ & $\mathrm{H} 26$ & $\mathrm{H} 27$ \\
\hline 呼吸器内科- 呼吸器外科 & 9.3 & 14.3 & 17.9 & 0.68 & 0.57 & 0.50 \\
\hline 脳外科 & 17.4 & 23.5 & 28.2 & 0.78 & 0.65 & 0.75 \\
\hline 泌尿器科 & 7.3 & 13.6 & 16.0 & 0.53 & 0.37 & 0.28 \\
\hline 耳鼻科 & 9.2 & 11.2 & 15.8 & 0.45 & 0.38 & 0.15 \\
\hline 眼科 & 6.7 & 10.7 & 16.8 & 0.00 & 0.09 & 0.00 \\
\hline 精神科 & 3.1 & 8.0 & 10.1 & 0.53 & 0.13 & 0.19 \\
\hline 整形外科 & 5.2 & 12.2 & 17.5 & 0.22 & 0.29 & 0.24 \\
\hline 産婦人科 & 11.3 & 13.3 & 16.1 & 0.00 & 0.56 & 0.31 \\
\hline 神経内科 & 10.6 & 25.4 & 16.3 & 0.55 & 1.35 & 0.37 \\
\hline 血液腫瘍内科 & 6.3 & 18.7 & 23.1 & 0.21 & 0.14 & 0.22 \\
\hline 心・腎内科 & 9.2 & 10.7 & 16.2 & 0.36 & 0.31 & 0.62 \\
\hline 消化器・肝臓内科 & 10.8 & 16.1 & 25.2 & 0.44 & 0.52 & 0.08 \\
\hline 皮膚科・産婦人科 & 11.0 & 14.1 & 15.1 & 0.56 & 0.62 & 0.44 \\
\hline 消化器外科 & 6.4 & 11.1 & 13.9 & 1.11 & 0.39 & 0.51 \\
\hline 小児科 & 10.8 & 15.7 & 18.6 & 0.99 & 0.66 & 0.88 \\
\hline 救急科 & 12.8 & 17.5 & 18.9 & 0.56 & 0.53 & 0.71 \\
\hline 口腔外科 & 9.0 & 13.8 & 16.9 & 0.36 & 0.54 & 0.18 \\
\hline 心臓血管外科 & 13.4 & 15.2 & 16.6 & 1.25 & 0.65 & 0.69 \\
\hline 循環器内科 & 7.3 & 10.4 & 13.2 & 0.07 & 0.07 & 0.15 \\
\hline \multirow{2}{*}{ クリティカル部門 } & \multicolumn{3}{|c|}{$\begin{array}{c}\text { ABHR 使用率 } \\
\text { (L/1,000patient-days) }\end{array}$} & \multicolumn{3}{|c|}{$\begin{array}{c}\text { MRSA の発生率 } \\
\text { (件数/1,000 patient-days) }\end{array}$} \\
\hline & $\mathrm{H} 25$ & $\mathrm{H} 26$ & $\mathrm{H} 27$ & $\mathrm{H} 25$ & $\mathrm{H} 26$ & $\mathrm{H} 27$ \\
\hline ER & 89.3 & 63.9 & 132.5 & 4.83 & 3.47 & 1.86 \\
\hline $\mathrm{ICU}$ & 64.6 & 100.4 & 158.7 & 4.98 & 2.24 & 0.51 \\
\hline MFICU & 31.5 & 32.9 & 29.2 & 0.00 & 0.00 & 0.00 \\
\hline $\mathrm{NICU}$ & 19.9 & 39.5 & 59.8 & 0.45 & 3.06 & 1.87 \\
\hline $\mathrm{CCU}$ & 23.4 & 30.7 & 37.9 & 0.00 & 3.48 & 4.05 \\
\hline ICU（循環器） & 22.3 & 45.7 & 55.0 & 2.12 & 0.93 & 1.44 \\
\hline
\end{tabular}

ER：救急センター, ICU：集中治療室, MFICU：母体胎児集中治療管理室

$\mathrm{NICU}:$ 新生児特定集中治療室

ABHR : alcohol-based hand rub

MRSA : methicillin-resistant Staphylococcus aureus

患者重複を除外して保菌者スクリーニングでの検出例も 含めた。

また, 本研究の副評価指標として, 平成 28 年 3 月に 看護師長 24 名に対する手指衛生向上に関するアンケー 卜を無記名で自記入選択式質問紙による調査を行った。 質問項目は 6 問とし，その内容は看護師長の手指衛生向 上に関する認識や自部署の ABHR 使用率の把握状況, 本 プログラムへの関与度，本プログラムで実際に関わった 具体的内容などを確認する目的で行った。

\section{6. 統計学的検討}

月別の ABHR 使用率および MRSA 発生率の比較は, それぞれ Mann-Whitney U 検定およびStudent $\mathrm{t}$ 検定に て解析し， $p<0.05$ を有意差ありとした（使用統計ソフ ト EZR Ver.1.27) ${ }^{12}$. また, 看護師長に対する意識調査 は, 項目別に百分率で単純集計した。

\section{7. 倫理的配慮}

本研究は, 岩手医科大学医学部倫理委員会の承認を得 て，個人情報保護に配虑し行った（承認番号 H28-172）。

\section{結 果}

一般病棟における月平均の ABHR 使用率 ( L/ 1,000 patient-days）は，プログラム導入前の平成 25 年度の 9.3 と比較して, 平成 26 年度が 14.5 および平成 27 年度が 17.5 と両者ともに有意に増加した $(p<0.05)$. MRSA 発生率 (件数 $/ 1,000$ patient-days) は, 平成 25 年度の 0.52 から, 平成 26 年度は 0.46 に減少し, 平成 27 年度では 0.37 と有意に減少した $(p<0.05)$. 同様に, クリティカ ル部門における $\mathrm{ABHR}$ 使用率も，平成 25 年度の 41.9 と比較して, 平成 26 年度が 52.2 および平成 27 年度が 78.8 と有意に増加した $(p<0.05)$. MRSA の発生率は, 平成 25 年度の 1.84 から, 平成 26 年度には 2.41 と増加 


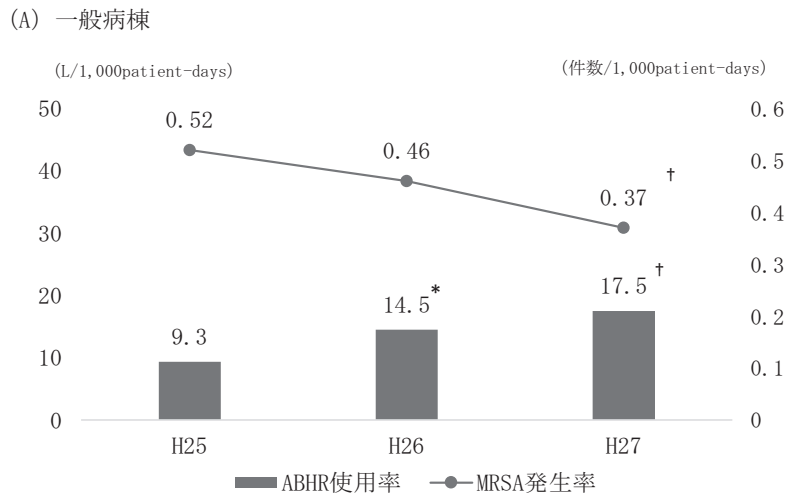

MRSA : methicillin - resistant Staphylococcus aureus ABHR : alcohol-based hand rub * $p<0.05$ ( H25 vs. H26 ) ${ }^{\dagger} p<0.05$ ( H25 vs. H27 )
(B) クリティカル部門

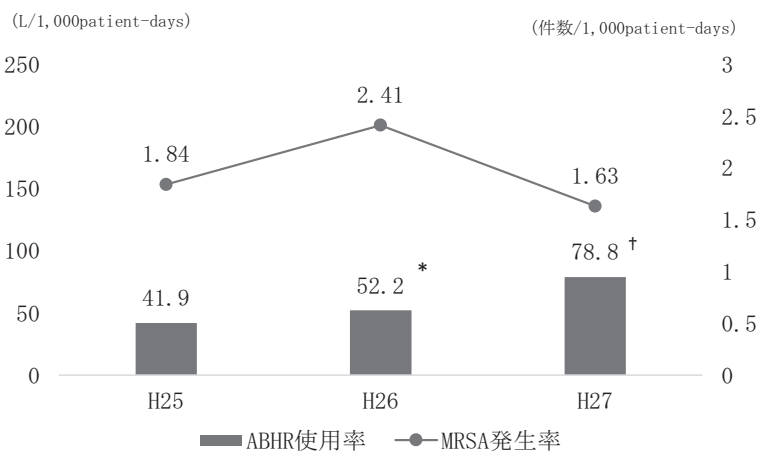

図 1 一般病棟およびクリティカル部門における ABHR 使用率と MRSA 発生率

したものの, 平成 27 年度は 1.63 に減少に転じた（図 1). 病棟別にみると, 一般病棟における ABHR 使用率は, 平成 25 年度に比べ, 平成 26 年度および平成 27 年度と もに, 19 病棟のすべてで増加した. ABHR 使用率の目 標達成病棟も平成 25 年度の 1 病棟から平成 27 年度では 16 病棟に増加した. MRSAの発生率は, 平成 25 年度 と比較して平成 27 年度では, 12 病棟で減少した。特に, 消化器外科病棟では, ABHR 使用率が平成 25 年度の 6.4 から平成 27 年度では 13.9 と倍増し $(p<0.05)$, 同時期 における MRSA の発生率が 1.11 から 0.51 へと半減した $(p<0.05)$. クリティカル部門でも, ABHR 使用率は, 平成 25 年度に比べて, 平成 27 年度では 6 病棟中 5 病棟 で増加し, MRSAの発生率を見ると 3 病棟で大きく減 少した。特に ICU では, ABHR 使用率が平成 25 年度の 64.6 から平成 27 年度では 158.7 と 2.5 倍に増加し $(p<$ 0.05), MRSAの発生率は 4.98 から 0.51 へと大きく減少 した $(p<0.05)$ (表 1).

看護師長へのアンケート結果（有効回答率 $100 \%$ ）で は, 手指衛生向上の目標設定は, すべての看護師長が「必 要または大いに必要である」と回答した。また, 自部署 の ABHR 使用率については, 87.5\% の看護師長が毎月 把握していた。 さらに, 看護師長の $95.8 \%$ が手指衛生 向上に「積極的に関与した」,「可能な限り関与した」と 答えていた，看護師長が介入した具体的内容については, 「リンクナースへの啓発」が $83.3 \%$ で,「ABHR 使用率 の確認」が $75.0 \%$,「スタッフへの直接指導」と「申し 送りで伝達」が $70.8 \%$ の順で高かった（表 2).

\section{考察}

本研究で導入したプログラムは, リンクナースと感染 症対策室を中心に介入したプログラム導入前と比較して ABHR 使用率を増加させ，目標值の達成に寄与した。さ
らに, MRSAの発生率は減少傾向を示した。病棟別に みても, ほとんどの一般病棟で ABHR 使用率は目標值 を達成し, クリティカル部門では ABHR 使用率が大き く増加した. ABHR 使用率増加に伴う MRSA 発生率の 減少は, 特に ER や ICU, 消化器外科病棟など MRSA の発生率が多い病棟で顕著であった。一方で, 精神科病 棟や循環器内科病棟などでは, ABHR 使用率の目標達 成には至らなかった. 両病棟とも外科系や他の内科系に 比べて手指衛生を行う機会が少ないことが要因と考えら れ，目標值の設定が高い可能性がある。この点について は，今後，適正な目標設定が必要である。また，NICU や CCU などでは ABHR 使用率が増えたにも関わらず, MRSA 発生率が増加した。これは, MRSA 発生に対す る感染対策の一環として, MRSAの保菌スクリーニン グを行った結果によるものと考える. 従って, 平成 26 年度のクリティカル部門において MRSA の増加が認め られたように, ABHR 使用率の増加と MRSA 発生率の 減少の解釈には, その病棟で行われた感染対策の背景も 考虑すべきである.

米国疾病管理予防センター (Centers for Disease Control and Prevention：CDC）が公表した「医療現場にお ける手指衛生のためのガイドライン」では, 手指衛生の 遵守向上のための行動戦略として, 施設管理側の姿勢や 制度の必要性を強調している ${ }^{13)}$. 当院では, 平成 25 年 度にリンクナースと感染症対策室が中心に，手指衛生向 上のための対策を統一的に実施した. 目標值の設定につ いても，看護部の業務目標としてではなかったものの, 本研究と同様に ABHR 使用率 (L/1,000patient-days) を 一般病棟で 15 , クリティカル部門で 30 と目標值を設定 して取り組んだ。しかし, ABHR 使用率は増加傾向を 示すものの目標達成には至らず, 病棟ごとの偏りも見ら れた。 そこで本研究では，プログラム導入前と同質の介 
表 2 看護師長に対する手指衛生の向上に関するアンケート結果

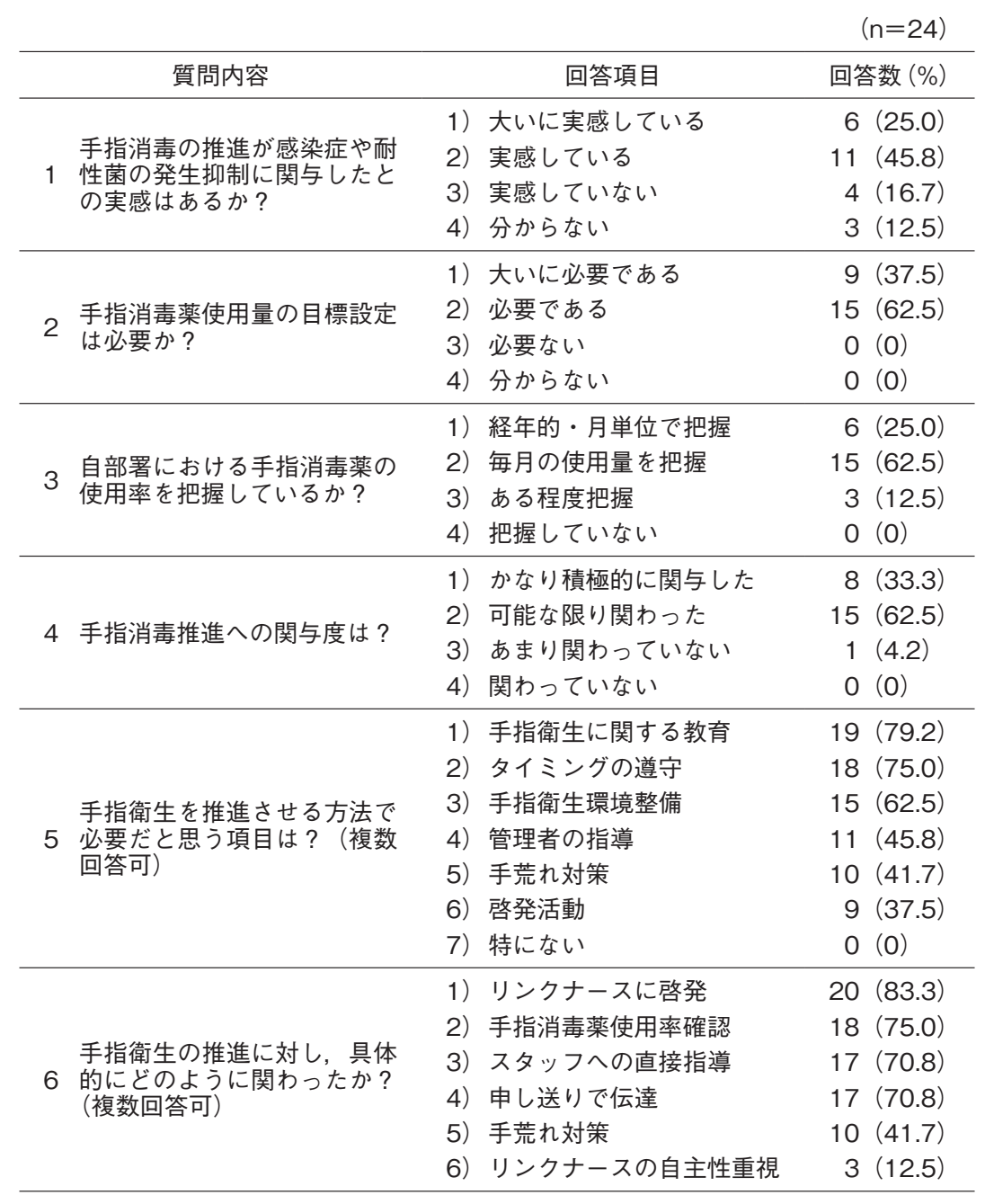

入に加えて，身近に存在し，影響力の強い看護師長の関 与に重点を置いて, 目標達成を試みた. 手指衛生の向上 に不可欠なスタッフの行動変容を促すには, 自ら手指衛 生の必要性を認識し, リンクナースが行う教育・啓発活 動や環境整備に, 精神的にもサポートするなど, エンパ ワーメントを機能させることでリンクナースの役割遂行 を支援することが必要である。この点において, 看護管 理者の役割は大きいと考える。木村ら ${ }^{14)}$ は「目標達成や 成果獲得のためには, 看護管理者が部下の行動能力の理 解や意欲をもたせる働きかけが必要であり，これが鍵と なる」と述べている，手指衛生を向上させるためには， 組織的な枠組みの中で目標を明確にし, 達成するための 戦略としてリンクナースの行動能力を最大限活かすマネ ジメントが求められる. 特に, 病院組織の中で最も大き い部門である看護部が率先して取り組む方針を掲げ，そ れに基づいて看護管理者がリーダーシップを取り, 病棟 での感染対策担当者であるリンクナースの役割遂行を支 援することが必要である。そして，目標達成の効果を実
感しながら手指衛生が習慣や文化となるような病棟の雲 囲気づくりが重要である.

本プログラムでは, 組織的な介入として看護部が ABHR 使用率の目標值を設定するとともに, 看護師長 会議における ABHR 使用率や MRSA 発生率のフィード バックと, 目標達成のための支援を継続的に行った。手 指衛生をはじめとする感染対策の推進による業務の増加 は, 反面, 手指衛生の障壁となり, 遵守率の低下につな がる可能性がある。しかし, 手指衛生を基本とした感染 管理は, 本来の重要な看護業務の一つと認識しなければ ならない。また, 今回の成果として MRSA 発生率の減 少を可視化することが，看護師長が感染対策の必要性を 認識し, リンクナースを中心に感染対策を推進すること ができたと考える。一方で, 本研究の限界として, 研究 期間中にプログラム実践中にリンクナースと感染症対策 室の継続的な感染対策支援があり, 看護師長の関与以外 の要素が影響している可能性がある. また, 看護師長の 手指衛生への関与度と目標達成効果について十分な検討 
ができなかった点や直接観察法が観察者の教育不十分に よる正確性に欠ける部分があるため, 今回の評価指標に 用いなかったことは今後の課題である. しかし, 本研究 で行ったアンケート調査では, 手指衛生への関与に理解 が得られ, リンクナースに対する啓発や指示, スタッフ に対する直接指導が行われていた。 その結果, ABHR 使用率が大きく増加し, 目標を達成していることから, 看護師長のエンパワーメントが機能したものと考える. 従って, 手指衛生の推進を看護部の目標として設定し, 病棟の中心的存在である看護師長の関与のもと組織全体 が積極的に取り組むことが効果的である．以上により， 看護管理者を対象とした本プログラムは, 手指衛生の向 上に有用であることが示唆された。

利益相反自己申告：申告すべきものなし.

\section{文献}

1) Novoa AM, Pi-Sunyer T, Sala M, Molins E, Castells X: Evaluation of hand hygine adherence in a tertiary hospital. Am J Infect Control 2007; 35: 676-83.

2) Lankford MG, Zemblower TR, Trick WE, Hacek DM, Noskin GA, Peterson LR: Influence of role models and hospital design on hand hygiene of healthcare workers. Emerg Infect Dis 2003; 9: 217-23.

3) Boyce JM, Pittet D: Centers for disease control and prevention, guideline for hand hygiene in health-care settings. Am J Infect Control 2002; 30: S1-S46.

4）大須賀ゆか：手指衛生を促進させるために，臨床看護 2007; 33(3): 352-6.
5）坂木晴世：日常業務に打減染防止対策 NICUに打ける 感染管理 感染管理認定看護師の立場から。 日本新生児看 護学 2007; 13(2): 38-42.

6) Bischoff WE, Reynolds TM, Sessler CN, Edmond MB, Wenzel RP: Handwashing compliance by health care workers: the impact of introducing an accessible, alcoholbased hand antiseptic. Arch Intern Med 2000; 160: 1017-21.

7）小野寺直人, 櫻井 滋, 吉田 優, 小林誠一郎, 高橋勝雄 : 大学附属病院における新たな感染制御支援策「感染経路別 ゾーニング・システム」導入の経緯と効果. 日本環境感染 誌 2008; 23(1): 58-65.

8）青木雅子, 北川洋子：NICUに扔ける手指衛生遵守率向上 に向けて〜ビデオを使用した手指衛生の適切なタイミング の評価〜．環境感染誌 2013; 28(2): 97-100.

9) Institute for Healthcare Improvement (IHI): How-to guide: improving hand hygiene $\sim$ a guide for improving practices among health care workers : 2006. p. 15-26.

10) Pittet D: Improving compliance with hand hygiene in hospitals. Infect Control Hosp Epidemiol 2000; 2(6): 381-6.

11) World Health Organization: WHO guidelines on hand hygiene in health care; first global patient safety challenge; clean care is safer care: World Health Organization, patient safety, Geneva, Switzerland, 2009.

12) Kanda Y: Investigation of he freely available easy-to-use software 'EZR' for medical statistics. Bone Marrow Transplant 2013; 48: 452-8.

13) Boyce JM, Pittet D: Guideline for Hand Hygiene in HealthCare Settings. MMWR 2002; 51(RR-16): 1-45.

14）木村チッ゙子：看護管理学習テキスト看護マネジメント論 第 2 版 第 3 巻, 木村チヅ子, 村上美好編, 井部俊子, 中西睦 子監，日本看護協会出版，東京，2015. p. 12-9.

〔連絡先： † 020-8505 岩手県盛岡市内丸 19-1 岩手医科大学附属病院医療安全管理部感染症対策室 沜 守一恵

E-mail: kazue.shimamori@j.iwate-med.ac.jp] 


\title{
Verification of Hand Hygiene Improvement Program for Nursing Administrators: Alcohol Based
} Hand Rub Usage and Detection Number of Methicillin-resistant Staphylococcus aureus

\author{
Kazue Shimamori ${ }^{1,2)}$, Keiko Kondou ${ }^{1,2)}$, Naoto OnODERA ${ }^{1,3)}$, \\ Etsuko SATO ${ }^{2)}$, Akira SuWABE ${ }^{3)}$ and Shigeru SAKURAI ${ }^{1)}$ \\ ${ }^{1)}$ Infection Control Office, Department of Medical Safety Administration, Iwate Medical University Hospital, \\ ${ }^{2)}$ Department of Nursing, Iwate Medical University Hospital, \\ ${ }^{3)}$ Department of Laboratory Medicine, Iwate Medical University School of Medicine
}

Abstract

Hand hygiene is an important infection control method to prevent healthcare-associated infections, but its compliance is not enough. We introduced a "hand hygiene improvement program" to encourage active involvement among nursing administrators, and analyzed the effect of this program on alcohol based hand rub (ABHR) usage rate and incidence rate (detection number / 1,000 patient days) of methicillin-resistant Staphylococcus aureus (MRSA). In this program, ABHR usage rate (L/1,000 patient days) was set to 15 in the general ward and 30 in the critical division as the work improvement objective of the nursing department, and obliged each nurse manager to achieve the goal. Also, at the nurse managers' conference, monthly ABHR usage rate and detection number of MRSA (cases/month) were reported. Furthermore, link nurse and infection control team collaborated to support goal-achievement. As a result, ABHR usage rate in general wards increased significantly from 9.3 in 2013 before introduction to 17.5 in 2015 after introduction $(\mathrm{p}<0.05)$ of program. The incidence rate of MRSA at the same time decreased significantly from 0.52 to $0.37(\mathrm{p}<0.05)$. Likewise, ABHR usage rate in the critical division also increased significantly from 41.9 in 2013 to 78.8 in $2015(\mathrm{p}<0.05)$. The incidence rate of MRSA at the same time showed a decreasing trend from 1.84 to 1.63 . These results suggest that it was effective to set the promotion of hand hygiene as the purpose of the nursing department and the entire organization tries actively under the involvement of the nurse manager who has a central role, and this program is useful for improving hand hygiene.

Key words: hand hygiene, alcohol based hand rub, methicillin-resistant Staphylococcus aureus, nursing administrators 